\title{
Potential and use of bacterial small RNAs to combat drug resistance: a systematic review
}

This article was published in the following Dove Press journal: Infection and Drug Resistance

\author{
Hung Chan ${ }^{1, *}$ \\ Jeffery $\mathrm{Ho}^{1, *}$ \\ Xiaodong Liu' \\ Lin Zhang ${ }^{1-3}$ \\ Sunny Hei Wong',4 \\ Matthew TV Chan' \\ William KK Wu ${ }^{1,2}$ \\ 'Department of Anesthesia and \\ Intensive Care, ${ }^{2}$ State Key Laboratory \\ of Digestive Disease, LKS Institute of \\ Health Sciences, ${ }^{3}$ School of Biomedical \\ Sciences, Faculty of Medicine, \\ ${ }^{4}$ Department of Medicine and \\ Therapeutics, the Chinese University \\ of Hong Kong, Shatin, Hong Kong \\ *These authors contributed equally to \\ this work
}

Correspondence: William KK Wu; Matthew TV Chan

The Chinese University of Hong Kong, 4/F, Main Clinical Block and Trauma Centre, Prince of Wales Hospital, Shatin, Hong Kong

Tel +8523505 3I 47; +8523505 2736

Email wukakei@cuhk.edu.hk; mtvchan@ cuhk.edu.hk
Background: Over the decades, new antibacterial agents have been developed in an attempt to combat drug resistance, but they remain unsuccessful. Recently, a novel class of bacterial gene expression regulators, bacterial small RNAs (sRNAs), has received increasing attention toward their involvement in antibiotic resistance. This systematic review aimed to discuss the potential of these small molecules as antibacterial drug targets.

Methods: Two investigators performed a comprehensive search of MEDLINE, EmBase, and ISI Web of Knowledge from inception to October 2016, without restriction on language. We included all in vitro and in vivo studies investigating the role of bacterial sRNA in antibiotic resistance. Risk of bias of the included studies was assessed by a modified guideline of Systematic Review Center for Laboratory Animal Experimentation (SYRCLE).

Results: Initial search yielded 432 articles. After exclusion of non-original articles, 20 were included in this review. Of these, all studies examined bacterial-type strains only. There were neither relevant in vivo nor clinical studies. The SYRCLE scores ranged from to 5 to 7 , with an average of 5.9. This implies a moderate risk of bias. sRNAs influenced the antibiotics susceptibility through modulation of gene expression relevant to efflux pumps, cell wall synthesis, and membrane proteins. Conclusion: Preclinical studies on bacterial-type strains suggest that modulation of sRNAs could enhance bacterial susceptibility to antibiotics. Further studies on clinical isolates and in vivo models are needed to elucidate the therapeutic value of sRNA modulation on treatment of multidrug-resistant bacterial infection.

Keywords: antibiotic susceptibility, small RNAs, bacterial resistance, systematic reviews, antibacterial target

\section{Introduction}

The presence of drug resistance in causative microbes is responsible for excessive mortality and length of hospital stay. ${ }^{1}$ In a matched cohort comparing bacteremic patients with third-generation cephalosporin-resistant Escherichia coli to those with -susceptible isolates, the former exhibited nearly fivefold increased risk for death in 30 days and had an excessive length of stay of 5 days attributable to infection with a resistant bacteria. ${ }^{2}$ In critically ill patients, the 28 -day mortality rate was twofold higher for patients infected with resistant bacteria comapred with those infected with a susceptible strain. ${ }^{3,4}$

The presence of resistant microbes limits the choice of antimicrobial chemotherapy. Traditional antimicrobials inhibit the essential synthesis of bacterial components, such as cell wall, membrane, and proteins. ${ }^{5,6}$ These involve a sophisticated network of 
enzymes encoded by multiple gene loci. Genetic sequence alteration of these loci is one of the mechanisms through which drug resistance is developed. ${ }^{78}$ These may involve synthesis of a novel protein altering the affinity to an existing drug or a novel enzyme, which is able to replace the functional enzyme otherwise inhibited by an antibiotic. ${ }^{9}$ Alternatively, drug resistance can be spread horizontally through conjugation, which transfers the drug resistance gene from the donor cell to the recipient cell by directly connecting cell surfaces with pili or adhesins. ${ }^{10,11}$

This traditional gene-protein paradigm in development of antibiotic resistance has recently been challenged by the recognition of an intermediate nucleotide, the small bacterial regulatory RNAs. The small RNAs (sRNAs), also known as regulatory sRNAs, exist in bacteria with a length of 50-500 nucleotides. ${ }^{12}$ Based on base-pairing algorithm, they are classified into $c i s$ - and trans-encoded sRNAs. Cis-encoded sRNAs are transcribed from the same loci as the mRNAs on the opposite strand of DNA and bind to their cognate mRNA targets with perfect complementarity, resulting in either transcriptional termination or translational initiation. ${ }^{12}$ Their actions are independent of chaperone. On the other hand, trans-encoded sRNAs do not display high specificity to a given mRNA. Instead, a given trans-encoded sRNA interacts with multiple mRNA targets. ${ }^{13,14}$ These trans-sRNAs are functionally dependent on chaperones. ${ }^{15} \mathrm{Hfq}$ and CsrA are essential chaperones for the activity of numerous transsRNAs. When Hfq and CsrA activity were inhibited and subsequently inhibited their downstream sRNA networks, bacterial infectiveness and susceptibility to antibiotics were reduced. ${ }^{16,17}$ The distribution of $c i s$ - and trans-sRNAs differs between Gram-positive and Gram-negative organisms. ${ }^{18}$ The biological mechanism of sRNA has been comprehensively reviewed. ${ }^{14}$ These sRNAs are important in controlling bacterial gene expression in response to extracellular stress and maintaining microbial cell homeostasis. ${ }^{19,20}$ By complementary binding to C-terminus of RNase or a promoter region of a transcription factor, the sRNA molecule either actively degrades the encoded proteins or halts the transcription of the encoded proteins..$^{21,22}$

Accumulating evidence suggests that sRNA is differentially expressed in bacterial transition from colonization to active infection ${ }^{23,24}$ and may represent one of the mechanisms for the organism to adapt to the changing environment as disease develops. ${ }^{25}$ Environmental stress such as exposure of antibiotics contributes to the physiological change of bacterial cells. Exposure of selective bacterial strains to antibiotics has revealed a panel of differentially expressed sRNAs. ${ }^{26-29}$
More importantly, overexpression of some of these sRNAs increases antibiotic susceptibility of the otherwise highly resistant bacterial strains. ${ }^{30,31}$ In this review, we performed a systematic search of the literature to discuss the therapeutic potential of these sRNAs in combating against the big problem of multidrug-resistant bacterial infection.

\section{Methods}

\section{Literature search}

We performed a search of published literature indexed in three electronic bibliographic databases: PubMed Medline, Web of Knowledge, and Embase. These search engines have previously been reported for use in systematic search. ${ }^{32}$ The search terms included a combination of "antibiotic resistance", "riboswitch", and "bacterial small RNA". Manual search of relevant articles was performed to identify other relevant articles. The details of manual search are as follows: titles of the studies were screened for match with predesigned inclusion criteria. The duplicate studies were eliminated among three databases. After that, abstracts of the eligible studies were screened by two authors and full-text articles were evaluated to determine whether they fulfilled the eligibility criteria. Publications from inception to October 2016 were included. Two authors ( $\mathrm{HC}$ and $\mathrm{JH}$ ) performed the literature search and eligibility assessment independently. Disagreements were resolved by consensus or discussion with senior authors. We followed suggestions from the Preferred Reporting Items for Systematic Reviews and Meta-Analyses (PRISMA) statement to conduct the literature search. ${ }^{32}$

\section{Selection criteria and data abstraction}

We included all in vitro and in vivo studies deciphering the role of bacterial sRNAs in antibiotic resistance. Review articles, editorials, commentaries, conference abstracts, and book chapters were excluded. Studies reporting bacterial ribosomal RNAs or other RNAs outside the 50-500 nucleotides range were excluded.

HC performed the data abstraction, which was then verified by another researcher $(\mathrm{JH})$. The following data were abstracted: author, year of publication, sample size, methods for detecting sRNAs, antibiotics used, and functional determination of sRNAs (Table 1).

\section{Quality assessment of the included studies}

The quality of the included studies was evaluated using a modified guideline from SYstematic review Center for Laboratory animal Experimentation (SYRCLE), an instrument 
Table I Summary of the included studies

\begin{tabular}{|c|c|c|c|c|c|c|c|}
\hline References & $\begin{array}{l}\text { Methods } \\
\text { for sRNA } \\
\text { detection } \\
\end{array}$ & $\begin{array}{l}\text { Sample } \\
\text { size }\end{array}$ & Small RNA & $\begin{array}{l}\text { Bacterial } \\
\text { species }\end{array}$ & $\begin{array}{l}\text { Target site of } \\
\text { sRNA }\end{array}$ & Antibiotics & Key findings \\
\hline $\begin{array}{l}\text { Molina- } \\
\text { Santiago } \\
\text { et } \mathrm{al}^{26}\end{array}$ & $\begin{array}{l}\text { RNA sequencing } \\
\text { genome analysis } \\
\text { Gene ontology } \\
\text { analysis }\end{array}$ & NA & NA & $\begin{array}{l}\text { Pseudomonas } \\
\text { putida } \\
\text { (DOT-TIE) }\end{array}$ & NA & $\begin{array}{l}\text { Chloramphenicol } \\
\text { Rifampicin } \\
\text { Tetracycline } \\
\text { Ciprofloxacin } \\
\text { Ampicillin } \\
\text { Kanamycin } \\
\text { Spectinomycin } \\
\text { Gentamicin }\end{array}$ & $\begin{array}{l}\text { Small RNA fine-tuned } \\
\text { the expression of } \\
\text { antibiotic resistance } \\
\text { genes }\end{array}$ \\
\hline $\begin{array}{l}\text { Howden } \\
\text { et } \mathrm{al}^{27}\end{array}$ & RNA-seq & $\begin{array}{l}\text { Not } \\
\text { mentioned }\end{array}$ & Not mentioned & $\begin{array}{l}\text { Staphylococcus } \\
\text { aureus }\end{array}$ & NA & $\begin{array}{l}\text { Vancomycin } \\
\text { Linezolid } \\
\text { Ceftobiprole } \\
\text { Tigecycline }\end{array}$ & $\begin{array}{l}\text { Antimicrobial- } \\
\text { responsive small } \\
\text { RNA associated } \\
\text { with the ribosomal } \\
\text { functions and protein } \\
\text { synthesis }\end{array}$ \\
\hline Yu et $\mathrm{al}^{28}$ & $\begin{array}{l}\text { Quantitative } \\
\text { real-time PCR } \\
\text { (qPCR) } \\
\text { Northern blots }\end{array}$ & 3 & sYJ75 & $\begin{array}{l}\text { Salmonella } \\
\text { enterica serovar } \\
\text { Typhimurium } \\
\text { SLI344 }\end{array}$ & $\begin{array}{l}\text { Iron- } \\
\text { enterobactin } \\
\text { transporter } \\
\text { periplasmic } \\
\text { binding protein } \\
\text { related genes }\end{array}$ & Tigecycline & $\begin{array}{l}\text { sYJ75 regulated } \\
\text { enterobactin } \\
\text { transport and } \\
\text { metabolism }\end{array}$ \\
\hline Chen et $\mathrm{al}^{29}$ & $\begin{array}{l}\text { qRT-PCR } \\
\text { Northern blots }\end{array}$ & $\geq 5$ & sCAC6IO & Clostridium genus & $\begin{array}{l}\mathrm{ABC} \\
\text { transporter } \\
\text { genes }\end{array}$ & Clindamycin & $\begin{array}{l}\text { sCAC } 610 \text { adjusted } \\
\text { downstream of } A B C \\
\text { transporter genes } \\
\text { and efflux pump } \\
\text { functions }\end{array}$ \\
\hline Kim et $\mathrm{al}^{30}$ & $\begin{array}{l}\text { DNA } \\
\text { sequencing } \\
\text { qRT-PCR } \\
\text { Northern blots }\end{array}$ & 3 & RyeB & Escherichia coli & $\begin{array}{l}\text { Muts } \\
\text { TolC } \\
\text { DnaK } \\
\text { LpxL }\end{array}$ & Levofloxacin & $\begin{array}{l}\text { RyeB enhanced the } \\
\text { therapeutic effect of } \\
\text { levofloxacin against } \\
\text { MDR strains }\end{array}$ \\
\hline Ramos et $\mathrm{al}^{31}$ & $\begin{array}{l}\text { Northern blots } \\
\text { Electrophoretic } \\
\text { mobility shift } \\
\text { assays } \\
\text { Western blots } \\
\text { Reverse } \\
\text { transcription- } \\
\text { PCR }\end{array}$ & $\geq 12$ & MtvR & $\begin{array}{l}\text { Escherichia coli } \\
\text { Pseudomonas } \\
\text { aeruginosa }\end{array}$ & $\begin{array}{l}\text { uhpA } \\
\text { uhpT }\end{array}$ & $\begin{array}{l}\text { Tetracycline } \\
\text { Chloramphenicol } \\
\text { Ciprofloxacin } \\
\text { Tobramycin } \\
\text { Gentamycin } \\
\text { Ampicillin }\end{array}$ & $\begin{array}{l}\text { MtvR increased } \\
\text { the sensitivity of } \\
\text { antibiotics }\end{array}$ \\
\hline Liu et $\mathrm{a}^{35}$ & $\begin{array}{l}\beta \text {-lactamase } \\
\text { assay }\end{array}$ & 3 & $\begin{array}{l}\text { Riboswitch with } \\
\text { theophylline- } \\
\text { specific aptamer } \\
\text { sequence }\end{array}$ & Escherichia coli & $\begin{array}{l}\beta \text {-lactamase } \\
\text { gene }\end{array}$ & $\begin{array}{l}\text { Ampicillin } \\
\text { Rifampin } \\
\text { Carbenicillin } \\
\text { Ciprofloxacin } \\
\text { Erythromycin } \\
\text { Amoxicillin } \\
\text { Cefamandole } \\
\text { Cefoxitin } \\
\text { Ceftazidime } \\
\text { Cephalexin } \\
\text { Piperacillin } \\
\text { Chloramphenicol } \\
\text { Nalidixic acid } \\
\text { Fusidic acid } \\
\text { Gentamicin }\end{array}$ & $\begin{array}{l}\text { Regulated } \\
\beta \text {-lactamase gene } \\
\text { expression to } \\
\text { decrease the } \\
\text { antimicrobial } \\
\text { susceptibility }\end{array}$ \\
\hline
\end{tabular}


Table I (Continued)

\begin{tabular}{|c|c|c|c|c|c|c|c|}
\hline References & $\begin{array}{l}\text { Methods } \\
\text { for sRNA } \\
\text { detection }\end{array}$ & $\begin{array}{l}\text { Sample } \\
\text { size }\end{array}$ & Small RNA & $\begin{array}{l}\text { Bacterial } \\
\text { species }\end{array}$ & $\begin{array}{l}\text { Target site of } \\
\text { sRNA }\end{array}$ & Antibiotics & Key findings \\
\hline Sharma et $\mathrm{al}^{36}$ & $\begin{array}{l}\text { qPCR } \\
\text { Northern blots } \\
\text { RACE }\end{array}$ & NA & AbsR25 & $\begin{array}{l}\text { Acinetobacter } \\
\text { baumannii }\end{array}$ & AIS_I331 & Excluded & $\begin{array}{l}\text { AbsR25 negatively } \\
\text { regulated the } \\
\text { efflux pump and } \\
\text { transporter }\end{array}$ \\
\hline $\begin{array}{l}\text { Johnson } \\
\text { et } \mathrm{al}^{37}\end{array}$ & $\begin{array}{l}\text { Northern blots } \\
\text { qRT-PCR } \\
\text { Western blots } \\
\text { Random } \\
\text { mutagenesis }\end{array}$ & $\geq 3$ & Anti-Q & $\begin{array}{l}\text { Enterococcus } \\
\text { faecalis }\end{array}$ & $\begin{array}{l}\text { prgQ } \\
\text { conjugation } \\
\text { operon }\end{array}$ & Excluded & $\begin{array}{l}\text { Anti-Q repressed the } \\
\text { conjugation among } \\
\text { bacteria }\end{array}$ \\
\hline Jia et $a^{38}$ & $\begin{array}{l}5^{\prime} \text { leader RNA } \\
\text { sequence } \\
\text { Native gel } \\
\text { electrophoresis } \\
\text { Crosslinking } \\
\text { analysis }\end{array}$ & 3 & $\begin{array}{l}\text { Aminoglycoside- } \\
\text { binding riboswitch }\end{array}$ & $\begin{array}{l}\text { Five } \\
\text { aminoglycoside } \\
\text { resistance genes } \\
\text { sequence was } \\
\text { used including } \\
\text { acetyl transferase, } \\
\text { phospho } \\
\text { transferase, } \\
\text { adenyl } \\
\text { transferase, } \\
\text { rRNA methyl } \\
\text { transferase, and } \\
\text { efflux pump genes }\end{array}$ & $\begin{array}{l}\text { Aminoglycoside } \\
\text { acetyl } \\
\text { transferase } \\
\text { (AAC) and } \\
\text { glycoside adenyl } \\
\text { transferase } \\
\text { (AAD) } \\
\text { resistance genes }\end{array}$ & $\begin{array}{l}\text { Kanamycin B } \\
\text { Sisomycin } \\
\text { Ribostamycin } \\
\text { Neamine }\end{array}$ & $\begin{array}{l}\text { Aminoglycoside- } \\
\text { binding riboswitch } \\
\text { involved in encoding } \\
\text { two aminoglycoside } \\
\text { antibiotics degrading } \\
\text { enzymes AAC and } \\
\text { AAD }\end{array}$ \\
\hline Baisa et $\mathrm{a}^{39}$ & $\begin{array}{l}\text { PCR } \\
\text { d-alanine } \\
\text { dehydrogenase } \\
\text { assays }\end{array}$ & 3 & GcvB & Escherichia coli & $c y c A$ & D-cycloserine & $\begin{array}{l}\text { GcvB involved in } \\
\text { the repression of } \\
\text { cycA gene which } \\
\text { encoded an enzyme } \\
\text { for antibiotics } \\
\text { D-cycloserine }\end{array}$ \\
\hline Knopp et $\mathrm{al}^{41}$ & $\begin{array}{l}\text { qRT-PCR } \\
\text { In-gel digestion } \\
\text { LC-MS }\end{array}$ & 3 & ChiX & Escherichia coli & chip & $\begin{array}{l}\text { Amikacin } \\
\text { Ampicillin } \\
\text { Azteronam } \\
\text { Cefaclor } \\
\text { Cefpirome } \\
\text { Cefuroxime } \\
\text { Chloramphenicol } \\
\text { Ciporfloxacin } \\
\text { Colistin } \\
\text { Erythromycin } \\
\text { Kanamycin } \\
\text { Mecillinam } \\
\text { Mupirocin } \\
\text { Nalidixic acid } \\
\text { Tetracycline } \\
\text { Sulfamethoxazole }\end{array}$ & $\begin{array}{l}\text { ChiX increased the } \\
\text { loss of } \\
\text { Chip porins which } \\
\text { conferred the } \\
\text { antibiotic resistance. }\end{array}$ \\
\hline Khan et $\mathrm{al}^{42}$ & $\begin{array}{l}\text { Northern blots } \\
\text { Large-scale liquid } \\
\text { culture }\end{array}$ & 3 & $\mathrm{GlmY}$ and $\mathrm{GlmZ}$ & Escherichia coli & $\mathrm{glmS}$ & Bacilysin & $\begin{array}{l}\text { GImY/GImZ } \\
\text { system shaped the } \\
\text { antibiotic resistance } \\
\text { by reactivation of } \\
\text { glmS enzyme in cell } \\
\text { envelope synthesis }\end{array}$ \\
\hline Chou et $\mathrm{al}^{43}$ & Northern blots & 3 & $\begin{array}{l}\text { micF encoded } \\
\text { sRNA }\end{array}$ & Escherichia coli & ompF & $\begin{array}{l}\text { Bleomycin } \\
\text { Kanamycin }\end{array}$ & $\begin{array}{l}\text { The soxRS mutations } \\
\text { were controlled by } \\
\text { the micF-encoded } \\
\text { sRNA }\end{array}$ \\
\hline
\end{tabular}


Table I (Continued)

\begin{tabular}{|c|c|c|c|c|c|c|c|}
\hline References & $\begin{array}{l}\text { Methods } \\
\text { for sRNA } \\
\text { detection }\end{array}$ & $\begin{array}{l}\text { Sample } \\
\text { size }\end{array}$ & Small RNA & $\begin{array}{l}\text { Bacterial } \\
\text { species }\end{array}$ & $\begin{array}{l}\text { Target site of } \\
\text { sRNA }\end{array}$ & Antibiotics & Key findings \\
\hline Allen et al ${ }^{44}$ & qPCR & 3 & $\begin{array}{l}\text { small RNA reg } \\
\text { micF }\end{array}$ & rEscherichia coli & $\begin{array}{l}a c r D \\
m d t A \\
m d t B\end{array}$ & $\begin{array}{l}\text { Carbenicillin } \\
\text { Tetracycline } \\
\text { Kanamycin }\end{array}$ & $\begin{array}{l}\text { Small RNA regulator } \\
\text { micF was irrelevant } \\
\text { to the carbenicillin } \\
\text { resistance in E. coli. }\end{array}$ \\
\hline Parker et $\mathrm{a}^{45}$ & $\begin{array}{l}\text { Northern blots } \\
\text { Western blots } \\
\text { Plasmid extraction }\end{array}$ & 3 & SdsR & $\begin{array}{l}\text { Escherichia coli } \\
\text { Vibrio cholera } \\
\text { Pseudomonas } \\
\text { aeruginosa }\end{array}$ & tolc & $\begin{array}{l}\text { Ampicillin } \\
\text { Novobiocin } \\
\text { Rifampicin } \\
\text { Erythromycin }\end{array}$ & $\begin{array}{l}\text { sdsR repressed the } \\
\text { tolC gene expression } \\
\text { for encoding } \\
\text { multidrug-resistance } \\
\text { efflux pumps } \\
\text { SdsR involved in } \\
\text { the minimization } \\
\text { of mismatch-repair } \\
\text { mutation which } \\
\text { resulted in antibiotics } \\
\text { resistance }\end{array}$ \\
\hline Eyraud et al ${ }^{46}$ & $\begin{array}{l}\text { Western blots } \\
\text { Northern blots } \\
\text { Toeprint assays }\end{array}$ & 4 & SprX & $\begin{array}{l}\text { Staphylococcus } \\
\text { aureus }\end{array}$ & SpoVG & $\begin{array}{l}\text { Vancomycin } \\
\text { Teicoplanin }\end{array}$ & $\begin{array}{l}\text { CU-rich domain } \\
\text { of SprX resulted } \\
\text { in vancomycin } \\
\text { and teicoplanin } \\
\text { glycopeptides } \\
\text { resistance by } \\
\text { inactivation of stage } \\
\text { V sporulation protein } \\
\text { G (SpoVG) }\end{array}$ \\
\hline Jeeves et $\mathrm{a}{ }^{47}$ & $\begin{array}{l}\text { Transcriptomic } \\
\text { analyses } \\
\text { qRT-PCR }\end{array}$ & $\begin{array}{l}\text { Not } \\
\text { mentioned }\end{array}$ & $\begin{array}{l}\text { G2 } \\
\text { MTSI082 }\end{array}$ & $\begin{array}{l}\text { Mycobacterium } \\
\text { tuberculosis }\end{array}$ & $\operatorname{efp} A$ & Excluded & $\begin{array}{l}\text { Antibiotic repressed } \\
\text { the expression of } \\
\text { sRNAs G2 and } \\
\text { MTSI } 082 \text { over time } \\
\text { at a slow growth rate }\end{array}$ \\
\hline Jackson et al ${ }^{48}$ & $\begin{array}{l}\text { Microarray } \\
\text { qRT-PCR }\end{array}$ & 3 & $\mathrm{NrrF}$ & $\begin{array}{l}\text { Neisseria } \\
\text { meningitidis } \\
\text { Neisseria } \\
\text { gonorrhoeae }\end{array}$ & $s d h A B$ & Excluded & $\begin{array}{l}\text { NrrF promoted } \\
\text { mRNA degradation } \\
\text { which encoded } \\
\text { antibiotic efflux pump }\end{array}$ \\
\hline Kim et $\mathrm{al}^{49}$ & qRT-PCR & 3 & RyhB-I & $\begin{array}{l}\text { Salmonella } \\
\text { typhimurium }\end{array}$ & $\begin{array}{l}\operatorname{acn} A \\
\operatorname{sod} B \\
\text { ftn } \\
\text { STMI273.In } \\
\operatorname{acn} B\end{array}$ & $\begin{array}{l}\text { Ampicillin } \\
\text { Norfloxacin }\end{array}$ & $\begin{array}{l}\text { RyhB-I repressed the } \\
\text { target gene to affect } \\
\text { the sensitivity to } \\
\text { antibiotics }\end{array}$ \\
\hline
\end{tabular}

Abbreviations: LC-MS, liquid chromatography-mass spectrometry; NA, data not available; PCR, polymerase chain reaction; qRT-PCR, quantitative real-time polymerase chain reaction; RACE, rapid amplification of cDNA ends; RNA-seq, ribonucleic acid sequencing.

based on the Cochrane Collaboration Risk of Bias tool. ${ }^{33,34}$ An item concerning random housing of animals was removed in the modified version. The remaining items assess selection bias, performance bias, detection bias, attribution bias, and reporting bias. These factors are common among in vitro and in vivo studies. Higher SYRCLE scores indicate better quality article. The maximum score is 9 .

\section{Results}

The initial search for the literature using three search engines yielded 432 eligible articles examining the bacterial small regulatory RNAs in the modulation of antibiotic resistance. Based on screening of the titles, abstracts, and keywords, we excluded 29 duplicated entries, 46 reviews, and 337 studies that are irrelevant to bacterial sRNA and antibiotics resistance, in which $32 \%$ of the studies are related to small molecule- or protein-mediating activity in antibiotics resistance without mentioning sRNA, 26\% to ribosomal RNAs in antibiotics resistance, $20 \%$ to the point mutation of bacterial strains without involvement of sRNA, $8 \%$ to a platform or method to screen or investigate the RNAs or protein in antibiotics resistance, and 4\% to new antibiotic-resistant clinical 
isolates or species. Eventually, 20 articles were included in our systematic review (Figure 1).

\section{Quality assessment of the included studies}

Overall, the SYRCLE scores ranged from 5 to 7, with an average of 5.9. This implies a moderate risk of bias (Table 2).

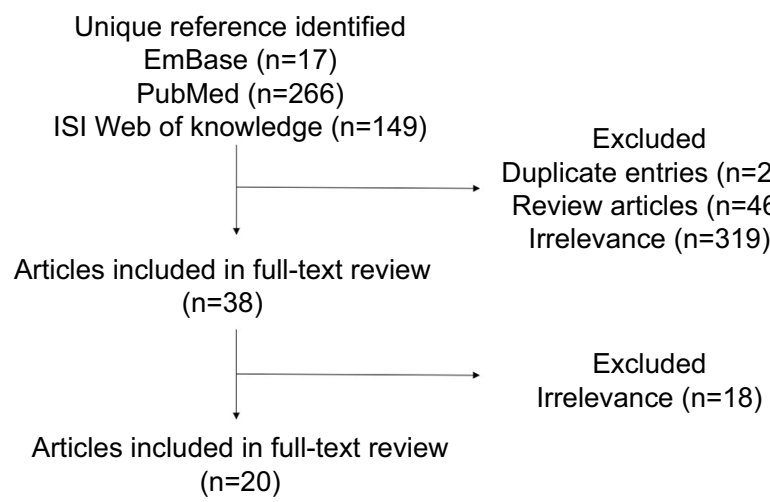

Figure I Selection of relevant scientific literature for systematic review.
None of the studies fulfilled the criteria for allocation concealment and experimental blinding. Four studies applied inadequate generation of allocation sequences. ${ }^{35-38}$ Several studies have demonstrated randomization for outcome assessment. $26,27,39,40$

\section{The species of bacteria included in the studies}

First, we reported the species of bacteria that are related to the sRNAs. The role of sRNAs has been examined largely in laboratory reference strains but not in clinical isolates. There were no relevant in vivo or clinical studies. A wide range of bacterial species were investigated in these studies, including Escherichia coli, Acinetobacter baumannii, Pseudomonas aeruginosa, Vibrio cholera, Salmonella typhimurium, Enterococcus faecalis, Neisseria meningitidis, Staphylococcus aureus, and Clostridium acetobutylicum. Seven studies were performed on E. coli, ${ }^{30,35,39,41,44 \text {, }}$ three on Pseudomonads, ${ }^{26,31,45}$ and two on Salmonella spp. ${ }^{27,46}$ The remaining genera were examined by a single study. ${ }^{29,35,36,47,48}$

Table 2 Summary of study quality assessment

\begin{tabular}{|c|c|c|c|c|c|c|c|c|c|c|}
\hline \multirow[t]{2}{*}{ References } & \multicolumn{3}{|c|}{ Selection bias } & \multirow{2}{*}{$\begin{array}{l}\text { Performance } \\
\text { bias } \\
\text { Q4 }\end{array}$} & \multicolumn{2}{|c|}{ Detection bias } & \multirow{2}{*}{$\begin{array}{l}\text { Attrition } \\
\text { bias } \\
\text { Q7 } \\
\end{array}$} & \multirow{2}{*}{$\begin{array}{l}\text { Reporting } \\
\text { bias } \\
\text { Q8 }\end{array}$} & \multirow{2}{*}{$\begin{array}{l}\text { Other } \\
\text { Q9 } \\
\end{array}$} & \multirow{2}{*}{$\begin{array}{l}\text { Total } \\
\text { score }\end{array}$} \\
\hline & $\overline{Q I}$ & Q2 & Q3 & & $\overline{Q 5}$ & Q6 & & & & \\
\hline Molina-Santiago et $\mathrm{a}^{26}$ & 1 & 1 & 0 & 0 & I & 1 & 1 & 1 & 1 & 7 \\
\hline Howden et $\mathrm{al}^{27}$ & I & I & 0 & 0 & I & I & I & I & I & 7 \\
\hline Yu et $\mathrm{al}^{28}$ & I & I & 0 & 0 & 0 & I & I & 1 & I & 6 \\
\hline Chen et $\mathrm{al}^{29}$ & I & I & 0 & 0 & I & I & I & I & I & 7 \\
\hline Kim et $\mathrm{al}^{30}$ & I & I & 0 & 0 & 0 & I & I & I & I & 6 \\
\hline Ramos et $\mathrm{al}^{31}$ & I & I & 0 & 0 & 0 & I & 1 & I & I & 6 \\
\hline Liu et $\mathrm{a}^{35}$ & 0 & I & 0 & 0 & 0 & I & I & I & I & 5 \\
\hline Sharma et $\mathrm{a}^{36}$ & 0 & I & 0 & 0 & 0 & I & I & I & I & 5 \\
\hline Johnson et $\mathrm{al}^{37}$ & 0 & I & 0 & 0 & 0 & 1 & I & I & I & 5 \\
\hline Jia et $\mathrm{al}^{38}$ & 0 & I & 0 & 0 & 0 & I & I & I & I & 5 \\
\hline Baisa et a $\left.\right|^{39}$ & I & I & 0 & 0 & I & I & I & I & I & 7 \\
\hline Knopp et $\mathrm{al}^{41}$ & I & I & 0 & 0 & 0 & 1 & I & I & 1 & 6 \\
\hline Khan et a $\left.\right|^{42}$ & I & I & 0 & 0 & 0 & I & I & I & I & 6 \\
\hline Chou et $\mathrm{al}^{43}$ & I & I & 0 & 0 & 0 & I & I & I & I & 6 \\
\hline Allen et a $\left.\right|^{44}$ & I & I & 0 & 0 & 0 & 1 & I & I & 1 & 6 \\
\hline Parker et al ${ }^{45}$ & I & I & 0 & 0 & 0 & I & I & I & I & 5 \\
\hline Eyraud et a $\left.\right|^{46}$ & I & 0 & 0 & 0 & 0 & I & I & I & I & 5 \\
\hline Jeeves et $\mathrm{al}^{47}$ & I & I & 0 & 0 & 0 & I & I & I & I & 6 \\
\hline Jackson et $\mathrm{al}^{48}$ & I & I & 0 & 0 & 0 & I & I & I & I & 6 \\
\hline Kim et $\mathrm{al}^{49}$ & I & I & 0 & 0 & 0 & I & I & I & I & 6 \\
\hline
\end{tabular}




\section{Experimental techniques for included studies to investigate bacterial sRNAs}

Second, experimental methods are essential to explore sRNAs or its targets. We classified the experimental techniques used in the included studies. Five studies performed functional investigation on bacterial sRNAs by profiling their expression patterns after exposure of bacterial strains to specific antibiotics. ${ }^{26-29,47}$ The remaining articles employed genetic silencing and modulation approach to evaluate the role of sRNA. Antibiotic resistance-encoding genes were either deleted or introduced into the experimental strains. ${ }^{30,31,35-49}$ This was followed by overexpression of sRNAs of interest in order to detect changes of antibiotic susceptibility. ${ }^{35-49}$

\section{Mechanism of sRNAs in antibiotics resistance}

Third, we elucidated the mechaisms of sRNAs in antibiotics resistance. The modulation of antibiotic sensitivity by sRNAs is pertinent to the synthesis of efflux pump, cell wall, transporters, and outer membrane proteins. The role of sRNAs in antibiotic resistance is summarized in Table 1 and Figure 2. The biological mechanism of sRNA is depicted in Figure 3.

The included studies have shown that regulated expression of bacterial sRNAs is important in sustaining antibioticresistant phenotypes and conferring bacterial survival advantage. ${ }^{26-31,47}$ Interestingly, experimental alteration of antibiotic-responsive sRNAs considerably increased bacterial susceptibility to various antibiotics..$^{30,31,49}$

\section{Discussion}

Although new antibacterial agents have been developed in an attempt to combat drug resistance, this remains largely unsuccessful. As soon as a new agent enters the market, the targeted bacteria develop novel strategies to minimize their susceptibility, shortening the lifespan of newly introduced antibiotics. This warrants continuous search for novel bacterial targets with less likelihood to induce drug resistance.

Bacterial sRNAs are regulatory molecules in response to the constant changes of the surrounding environment. ${ }^{30,42,43}$ As such, sRNAs are important for bacterial adaptability in the presence of harmful substances. By translational bypassing, these short-sequence nucleotides respond promptly to antimicrobial challenge. ${ }^{14}$ With non-specific and imperfect binding to mRNAs, these sRNA molecules can modulate the activity of multiple mRNAs simultaneously. ${ }^{50}$ Given the essential pathways and multiple targets regulated by a given sRNA, modulation of this moiety may be a promising therapeutic approach with less likelihood of antimicrobial resistance development. This is because the sRNAs modulate the translation process of antmicriobial resistant genes instead of whole bacterial genome. ${ }^{51}$ In addition, sRNA targeting mRNA sequences distinct from those in humans will exhibit excellent selective toxicity. This will provide an alternative therapy to highly toxic antibiotics such as aminoglycosides.

\section{sRNAs involved in mutation-induced antibiotic resistance}

After exposure to antibiotics in sublethal concentration, bacterial growth is hindered and mutagenesis is favored. ${ }^{47,52}$

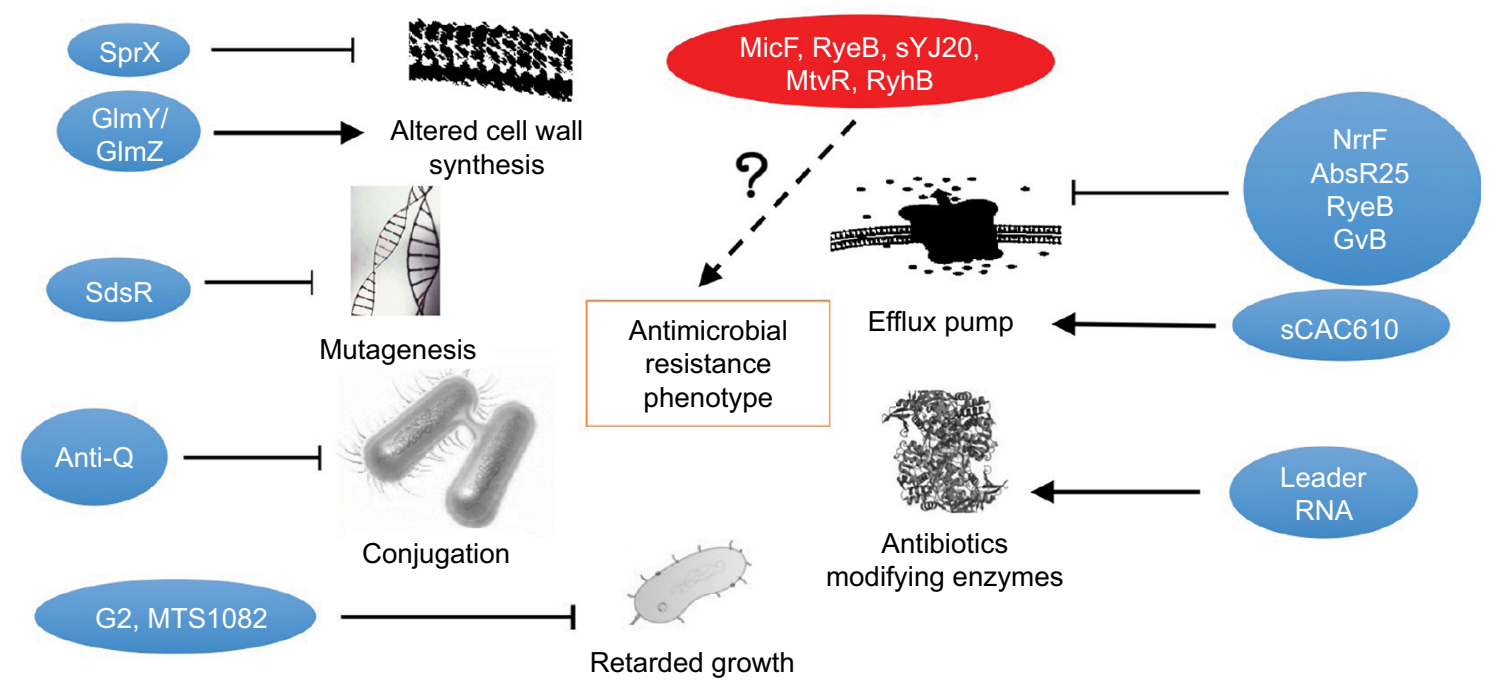

Figure 2 Small bacterial RNAs interact with canonical (in blue) and unknown mechanisms (in red) in acquisition of antimicrobial resistance phenotype. The pointed arrowheads denote putative stimulatory effect whereas the blunted arrowheads represent inhibitory actions. 


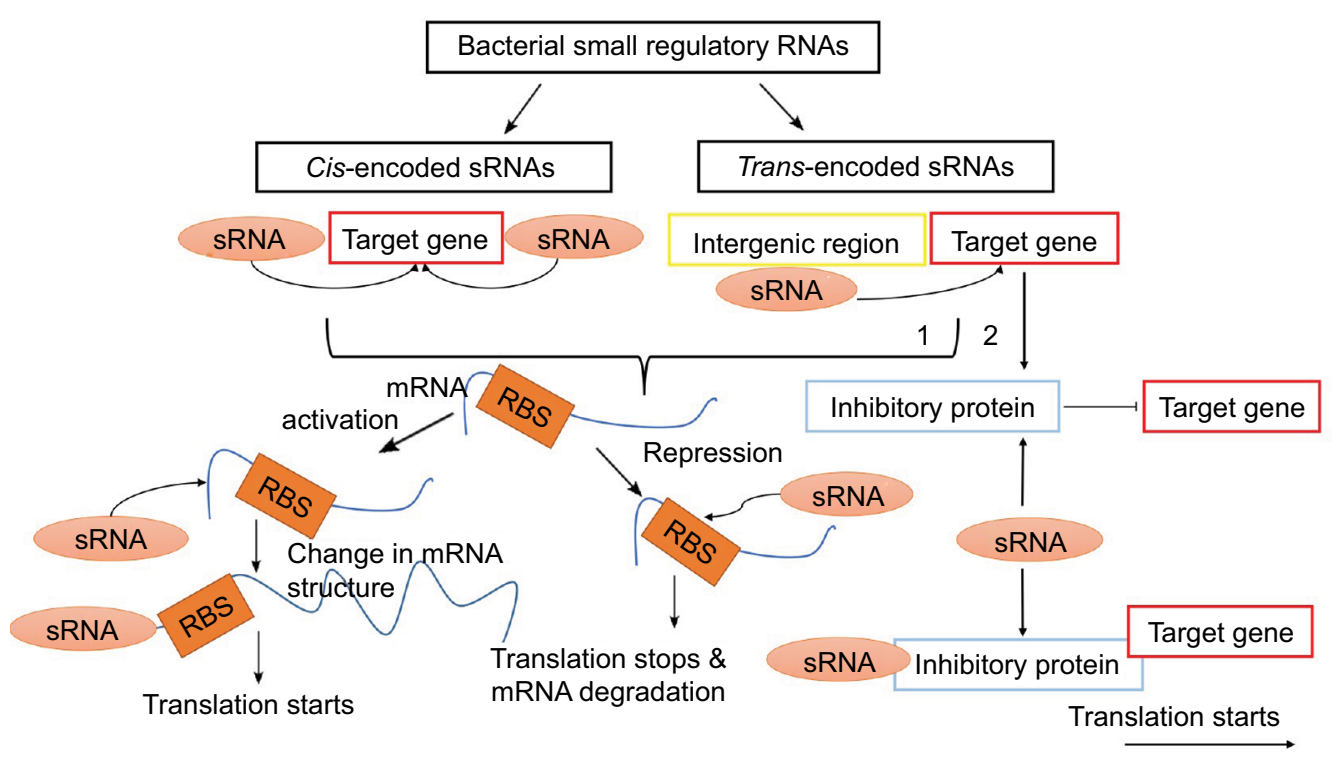

Figure 3 The biological action of small bacterial RNAs. These molecules are classified into cis- and trans-encoded sRNAs. By binding to non-coding region of mRNA or a gene per se, sRNAs either activate or repress the expression of a given protein. Abbreviation: RBS, RNA binding site.

For instance, the expression of sRNAs G2 and MTS1082 in Mycobacterium tuberculosis was repressed at stationary phase of growth, which is associated with their antibiotictolerant phenotype. ${ }^{47}$ In E. coli, the presence of growthlimiting stressor induced a transcription factor known as $R p o S$ regulon. ${ }^{52}$ This complex leads to subsequent expression of $s d s R$, an $R p o S$-dependent sRNA..$^{52,53}$ This negatively regulated the ampicillin-induced mutagenesis by binding to mutS, an mRNA molecule encoding protein for mismatch detection. $^{53}$

\section{Pro-survival benefits via modulating sRNA expression}

The sRNA molecule is important for bacterial survival in the presence of antimicrobial challenge. In Staphylococcus aureus, exposed to a combination of vancomycin, linezolid, ceftobiprole, and tigecycline, expression of specific sRNAs was prominent. The change in the expression of these sRNAs maintains protein synthesis and ribosomal function in the presence of antimicrobial challenge, thereby ensuring bacterial survival. ${ }^{26,27,31}$ Upon the exposure of antibiotics, genes coding proteins including metabolism, transport, transcriptional regulation, and ribosome proteins are unregulated. ${ }^{26}$ In the presence of tigecycline and tetracycline, sRNA sYJ20 was upregulated in Salmonella typhimurium. Deletion of sYJ20 reduced the bacterial survival rate upon exposure to tigecycline.$^{28}$ sRNA sYJ20 regulated the antibiotic tolerance through modulation of tigecycline and tetracycline relevant encoding genes.

\section{Increasing antimicrobial sensitivity by targeting sRNAs}

Modulation of sRNAs has been shown to increase bacterial sensitivity to antibiotics. Experimental upregulation of sRNA, MtvR, enhanced the sensitivity of E. coli to tetracycline, chloramphenicol, ciprofloxacin, tobramycin, gentamycin, and ampicillin by two- to eightfold. ${ }^{30}$ In Pseudomonas aeruginosa, overexpression of MtvR significantly suppressed their growth upon exposure to chloramphenicol, ciprofloxacin, tetracycline, tobramycin, gentamycin, and ampicillin. ${ }^{31}$ Conversely, sRNA-induced modulation of antibiotic susceptibility was reversed by depletion of the respective sRNAs. ${ }^{30,31}$

In response to ampicillin and norfloxacin, the expression pattern of RyhB sRNA changed considerably in E. coli. Ampicillin and norfloxacin share common pathways in the production of highly deleterious hydroxyl radicals in the tricarboxylic acid cycle (TCA). ${ }^{54}$ The RyhB sRNA targets AcnA, a gene encoding the TCA cycle-related enzyme in E. coli. ${ }^{49,55}$ Perturbation of the TCA cycle-related enzymes triggers TCA cycle dysfunctions and subsequently makes bacteria less susceptible to $\beta$-lactam antibiotics by altering its cell surface properties. ${ }^{56}$

Although accumulating evidence has suggested that modulating sRNA expression alters bacterial susceptibility to antibiotics, these appear to be strain specific. In addition, laboratory reference strains may not reflect clinical situation as type strains likely behave differently from clinical strains. ${ }^{57}$ To extrapolate these findings into therapeutic drug development, the candidate sRNA should be universally responsive 
to a given antibiotic in different strains of the same bacterial genus, or at least be consistently responsive in the same species. Clinical isolates should be thoroughly tested with complete profile of pharmacokinetics and pharmacodynamics of the exogenous sRNA modulators established.

\section{Reversal of efflux pump-mediated resistance}

The presence of multidrug efflux pump represents one of the important mechanisms conferring antibiotic resistance. It prevents the accumulation of drugs in bacterial cells, enabling the bacteria to survive. In Acinetobacter baumannii, an efflux pump regulating sRNA-designated AbsR 25 was initially recognized by its high hybridization energy. ${ }^{36}$ In E. coli, AcrAB-TolC represents a major efflux pump conferring multidrug-resistant phenotype. ${ }^{58}$ Deletion of tolC rendered the mutants more sensitive to antibiotics as compared to the wild-type counterparts. ${ }^{59}$ The sRNA sdsR, or alternatively known as RyeB, post-transcriptionally represses the expression of tolC by base-pairing with its $5^{\prime}$-untranslated region (5'-UTR) ${ }^{45}$ MicF represents another important sRNA which is presumably involved in the regulation of efflux pumps. The $\mathrm{MicF}$ is a two-component response regulator contributing to carbenicillin resistance. In E. coli, the sRNA MicF response regulator inhibited the transcription of the $o m p F$ gene encoding porins, which reduced the pore-forming antibiotics such as $\beta$-lactams to enter the cell interior. ${ }^{44}$ In Neisseria species, trans-acting sRNA NrrF played a crucial role in transcriptional control of efflux pump synthesis. Experimental overexpression of $\mathrm{NrFF}$ decreased the antibiotic-induced expression of efflux pumps. ${ }^{48}$

Other transporters in bacteria were correlated with the efflux pumps and further implicated the antibiotic resistance in bacteria. ${ }^{60}$ In Clostridium acetobutylicum, the sRNA sCAC610 regulates ATP binding cassette transporter genes. ${ }^{29}$ In the presence of clindamycin, the level of sCAC610 was significantly upregulated. Bioinformatics analysis revealed that sCAC610 modulated efflux pump function through cisregulation. ${ }^{29} \mathrm{D}$-cycloserine (DCS) is a second-line antibiotic for the treatment of multidrug-resistant Mycobacterium tuberculosis. ${ }^{61}$ In this organism, an sRNA molecule GcvB suppressed the expression of $c y c A$, a gene encoding an enzyme for degradation of DCS..$^{39,62}$

Collectively, targeted delivery of sRNA agonists or antagonists may represent alternative approach to combat against multidrug-resistant Enterobacteriaceae and tubercle bacilli.

\section{Reversal of resistance to cell wall inhibitors}

Resistance to cell wall synthesis inhibitors predominantly involves overproduction of degradative enzymes and formation of alternative membrane protein with low affinity to antibiotics. Penicillins and cephalosporins are major antibiotic classes under this category. Recently, it has been appreciated that some sRNAs are activated upon encountering cell wall synthesis inhibitors in an attempt to restore cell wall integrity. Bacilysin, a peptide antibiotic, inhibits glucosamine-6-phosphate synthase (GlmS) activity and thereby interferes with cell wall synthesis. However, suppression of GlmS by bacilysin in E. coli activates the expression of two sRNAs, namely GlmY and GlmZ, which in return restore the expression of GlmS, this resulting in a resistance phenotype. ${ }^{42}$ In this connection, co-administration of bacilysin with GlmY/GlmZ antagonist may reduce the therapeutic dose of the antibiotics concerned.

The increasing prevalence of methicillin-resistant Staphylococcus aureus with reduced susceptibility to vancomycin represents another important public health threat. To date, the mechanisms contributing to this non-susceptibility remain unclear, although point mutation and thickening of cell walls have been suggested. ${ }^{7}$ Comparative proteomic studies revealed that a small RNA molecule $\mathrm{SprX}$ inhibits the expression of stage $V$ sporulation protein $\mathrm{G}$ (SpoVG), a moiety contributing to non-susceptibility to glycopeptides. ${ }^{46,62}$ It remains unclear under which condition this RNA molecule is activated. However, this suggests that co-administration of SprX activators with glycopeptides may reduce the likelihood of resistance development during therapy. Whether this combination results in synergy or antagonism will need to be elucidated.

\section{Reversal of minimal membrane permeability-mediated resistance}

One of the important mechanisms by which Gram-negative bacteria gain survival benefits in face of antibiotic challenge is reducing their outer membrane permeability to aqueous drugs by loss of porins. ${ }^{43,63}$ The control of the porins' expression has been studied thoroughly in E. coli. It has been shown that mutation of soxRS reduced the expression of a major drug target porin, namely $O m p F$, through a sRNA molecule called micF ${ }^{64}$ As such, inhibition of micF sensitizes bacteria to aqueous antibiotics. ${ }^{43}$ Serial passage of laboratory strains of $E$. coli has revealed the acquisition of an alternative porin called Chip in compensation for the loss of drug target porins $O m p C$ and $O m p F{ }^{41}$ Further molecular characterization led to identification of a sRNA known as ChiX, which 
downregulates the expression of Chip porins and restores the bacterial susceptibility to carbapenams. ${ }^{41}$

\section{Reversal of other drug resistance mechanisms}

Bacterial riboswitch is a cis-encoded sRNA situated at the non-coding region of mRNA. ${ }^{35,38,40}$ The aptamer domain of this RNA molecule binds to specific metabolites, thereby exerting post-transcriptional control of their expression. ${ }^{65,66}$ In Enterobactericeae, the presence of a riboswitch with theophylline-specific aptamer sequence mediates the production of a range of $\beta$-lactamases which further confer $\beta$-lactam antibiotic resistance. ${ }^{35}$ Therefore, $\beta$-lactam antibiotic resistance can be eliminated by reduction of this riboswitch activity. In aminoglycoside resistance, the major mechanism is attributable to the presence of nucleotidyltransferases, which modify the drug and render it ineffective. These enzymes are mainly encoded by $a a c$ and aad genes. The $5^{\prime}$ leader RNA, a riboswitch, of the aac/aad genes interacts with aminoglycosides and in turn activates the expression of the modifying enzymes. ${ }^{38,40,67}$ In this regard, development of an antagonist, which prevents the binding of aminoglycosides to the leader sequence, may be useful to avoid the development of inducible resistance. Alternatively, modification of side chains of the next-generation aminoglycoside can facilitate their interaction with $30 \mathrm{~S}$ ribosomal subunit rather than the $5^{\prime}$ leader sequence leading to transcription of degradative enzymes.

Transfer of resistance determinants across bacterial species by conjugation has been increasingly recognized as a novel strategy by which bacteria acquire drug resistance. ${ }^{68}$ This may be an important reason, if not the only one, which accounts for epidemiology peculiarity of antibiotic resistance. In Enterococcus faecalis, a small RNA molecule called anti-Q has been shown to suppress the conjugation of the plasmid pCF 10 by termination of prgX repression and prgQ conjugation operons. ${ }^{37}$

In this connection, conjugation suppressor sRNAs may be employed to prevent inter-bacterial transfer of resistance determinants. Development of air spray containing these suppressor molecules may be applicable for use in environments such as intensive care units to prevent interspecies transfer of resistance determinants.

\section{Concluding remarks and future perspectives}

Experimental studies using type strains have suggested that targeting sRNA increased their susceptibility to antibiotics in the otherwise resistance strains. Unlike conventional antibiotics, sRNA is a powerful master regulator in gene regulation which inhibited the translation of bacterial protein synthesis. sRNA has a great potential to develop as a novel drug or become a novel acceessory ingredient in medical use. Given multiple targets of a single sRNA molecule, modulating sRNAs in bacterial strains in vivo using bacteriophages or nanoparticles may be a promising therapeutic approach in clinical use. Co-administration of sRNA agonist or antagonist with conventional antibiotics may represent an alternative option to minimize the emergence of resistance during therapy. Further studies with clinical isolates and in vivo models are necessary to elucidate the real clinical situation and therapeutic potential of sRNA modulators.

\section{Acknowledgments}

This study was funded by Health and Medical Research Fund (15140132); Commissioned Research on Control of Infectious Disease (Phase III) (CU-15-B2), Food and Health Bureau, Hong Kong; and internal research fund of the Department of Anesthesia and Intensive Care, Faculty of Medicine, the Chinese University of Hong Kong. The authors would like to thank Wai T Wong, Thomas Kwong, Gordon Choi, Czarina CH Leung, Sharon Tsang, Tony Gin, Jun Yu, and Gary Tse for their contribution to this manuscript. As they did not fulfill the criteria for authorship according to Good Publication Practice 3 guideline, we apologise for not listing them as co-authors.

\section{Disclosure}

The authors report no conflicts of interest in this work.

\section{References}

1. de Kraker ME, Wolkewitz M, Davey PG, et al. Clinical impact of antimicrobial resistance in European hospitals: excess mortality and length of hospital stay related to methicillin-resistant Staphylococcus aureus bloodstream infections. Antimicrob Agents Chemother. 2011;55(4):1598-1605.

2. de Kraker ME, Wolkewitz M, Davey PG, et al. Burden of antimicrobial resistance in European hospitals: excess mortality and length of hospital stay associated with bloodstream infections due to Escherichia coli resistant to third-generation cephalosporins. J Antimicrob Chemother. 2011; 66:398-407.

3. Combes A, Luyt CE, Fagon JY, et al. Impact of pieracillin resistance on the outcome of Pserudomonas ventilator-associated pneumonia. Intensive Care Med. 2006;32:1970-1978.

4. Tabah A, Koulenti D, Laupland K, et al. Characteristics and determinants of outcome of hospital-acquired bloodstream infections in intensive care units: the EUROBACT International Cohort Study. Intensive Care Med. 2012;38:1930-1945.

5. Nikolaidis I, Favini-Stabile S, Dessen A. Resistance to antibiotics targeted to the bacterial cell wall. Protein Sci. 2014;23:243-259.

6. Bakheet TM, Doig AJ. Properties and identification of antibiotic drug targets. BMC Bioinformatics. 2010;11:195.

7. Levy SB. The 2000 Garrod lecture. Factors impacting on the problem of antibiotic resistance. J Antimicrob Chemother. 2002;49:25-30. 
8. Doddangoudar VC, Boost MV, Tsang DN, et al. Tracking changes in the vraSR and graSR two component regulatory systems during the development and loss of vancomycin non-susceptibility in a clinical isolate. Clin Microbiol Infect. 2011;17:1268-1272.

9. Kohanski MA, Dwyer DJ, Collins JJ. How antibiotics kill bacteria: from targets to networks. Nat Rev Microbiol. 2010;8(6):423-435.

10. Smillie C, Garcillan-Barcia MP, Francia MV, et al. Mobility of plasmids. Microbiol Mol Biol Rev. 2010;74:434-452.

11. Wozniak RA, Waldor MK. Integrative and conjugative elements: mosaic mobile genetic elements enabling dynamic lateral gene flow. Nat Rev Microbiol. 2010;8:552-563.

12. Kwenda S, Gorshkov V, Ramesh AM, et al. Discovery and profiling of small RNAs responsive to stress conditions in the plant pathogen Pectobacterium atrosepticum. BMC Genomics. 2016;17:47.

13. Vogel J, Wagner EG. Target identification of small noncoding RNAs in bacteria. Curr Opin Microbiol. 2007;10:262-270.

14. Waters LS, Storz G. Regulatory RNAs in bacteria. Cell. 2009;136: 615-628.

15. Ellis MJ, Trussler RS, Haniford DB. A cis-encoded sRNA, Hfq and mRNA secondary structure act independently to suppress IS200 transposition. Nucleic Acids Res. 2015;43:6511-6527.

16. Oliva G, Sahr T, Buchrieser C. Small RNAs, 5' UTR elements and RNA-binding proteins in intracellular bacteria: impact on metabolism and virulence. FEMS Microbiol Rev. 2015;39(3):331-349.

17. Muhlen S, Dersch P. Anti-virulence strategies to target bacterial infections. Curr Top Microbiol Immunol. 2016;398:147-183.

18. Jousselin A, Metzinger L, Felden B. On the facultative requirement of the bacterial RNA chaperone, Hfq. Trends Microbiol. 2009;17: 399-405.

19. Vogel J, Luisi BF. Hfq and its constellation of RNA. Nat Rev Microbiol. 2011;9:578-589.

20. Zhou Y, Xie J. The roles of pathogen small RNAs. J Cell Physiol. 2011;226:968-973.

21. Morita T, Maki K, Aiba H. RNase E-based ribonucleoprotein complexes: mechanical basis of mRNA destabilization mediated by bacterial noncoding RNAs. Genes Dev. 2005;19:2176-2186.

22. Bouvier M, Sharma CM, Mika F, et al. Small RNA binding to $5^{\prime}$ mRNA coding region inhibits translational initiation. Mol Cell. 2008;32:827-837.

23. Nithya R, Ahmed SA, Hoe CH, et al. Non-protein coding RNA genes as the novel diagnostic markers for the discrimination of Salmonella species using PCR. PLoS One. 2015; 10:e0118668.

24. Song J, Lays C, Vandenesch F, et al. The expression of small regulatory RNAs in clinical samples reflects the different life styles of Staphylococcus aureus in colonization vs. infection. PLoS One 2012;7:e37294.

25. Xia L, Xia W, Li S, et al. Identification and expression of small noncoding RNA, L10-Leader, in different growth phases of Streptococcus mutans. Nucleic Acid Ther. 2012;22:177-186.

26. Molina-Santiago C, Daddaoua A, Gomez-Lozano M, et al. Differential transcriptional response to antibiotics by Pseudomonas putida DOTT1E. Environ Microbiol. 2015;17:3251-3262.

27. Howden BP, Beaume M, Harrison PF, et al. Analysis of the small RNA transcriptional response in multidrug-resistant Staphylococcus aureus after antimicrobial exposure. Antimicrob Agents Chemother 2013;57:3864-3874.

28. Yu J, Schneiders T. Tigecycline challenge triggers sRNA production in Salmonella enterica serovar Typhimurium. BMC Microbiol. 2012;12:195.

29. Chen YL, Indurthi DC, Jones SW, et al. Small RNAs in the genus Clostridium. mBio. 2011;2:e0340-10.

30. Kim T, Bak G, Lee J, et al. Systematic analysis of the role of bacterial Hfq-interacting sRNAs in the response to antibiotics. J Antimicrob Chemther. 2015;70:1659-1668.

31. Ramos CG, Grilo AM, Sousa SA, et al. Regulation of Hfq mRNA and protein levels in Escherichia coli and Pseudomonas aeruginosa by the Burkholderia cenocepacia MtvR sRNA. PLoS One. 2014;9:e98813.
32. Liberati A, Altman DG, Tetzlaff J, et al. The PRISMA statement for reporting systematic reviews and meta-analyses of studies that evaluate health care interventions: explanation and elaboration. JClin Epidemiol. 2009;62:e1-34.

33. Hooijmans CR, Rovers MM, de Vries RB, et al. SYRCLE's risk of bias tool for animal studies. BMC Med Res Methodol. 2014;14:43.

34. Ho J, Chan $\mathrm{H}$, Wong $\mathrm{H}$, et al. The involvement of regulatory non-coding RNAs in sepsis: a systematic review. Crit Care. 2016;20:383.

35. Liu L, Wang S. Engineered riboswitch as a gene-regulatory platform for reducing antibiotic resistance. Methods Mol Biol. 2014;1111:251-258.

36. Sharma R, Arya S, Patil SD, et al. Identification of novel regulatory small RNAs in Acinetobacter baumannii. PLoS One. 2014;9:e93833.

37. Johnson CM, Chen YQ, Lee $\mathrm{H}$, et al. Identification of a conserved branched RNA structure that functions as a factor-independent terminator. Proc Natl Acad Sci U S A. 2014;111:3573-3578.

38. Jia X, Zhang J, Sun WX, et al. Riboswitch control of aminoglycoside antibiotic resistance. Cell. 2013;152:68-81.

39. Baisa G, Stabo NJ, Welch RA. Characterization of Escherichia coli D-cycloserine transport and resistant mutants. J Bacteriol. 2013;195:1389-1399.

40. Chen D, Murchie AI. An aminoglycoside sensing riboswitch controls the expression of aminoglycoside resistance acetyltransferase and adenyltransferases. Biochim Biophys Acta. 2014;1839:951-958.

41. Knopp M, Andersson DI. Amelioration of the fitness costs of antibiotic resistance due to reduced outer membrane permeability by upregulation of alternative porins. Mol Biol Evol. 2015;32:3252-3263.

42. Khan MA, Gopel Y, Milewski S, et al. Two small RNAs conserved in Enterobacteriaceae provide intrinsic resistance to antibiotics targeting the cell wall biosynthesis enzyme glucosamine-6-phosphate synthase. Front Microbiol. 2016;7:908.

43. Chou JH, Greenberg JT, Demple B. Posttranscriptional repression of Escherichia coli OmpF protein in response to redox stress: positive control of the micF antisense RNA by the soxRS locus. $J$ Bacteriol. 1993;175:1026-1031.

44. Allen HK, An R, Handelsman J, et al. A response regulator from a soil metagenome enhances resistance to the beta-lactam antibiotic carbenicillin in Escherichia coli. PLoS One. 2015;10:e120094.

45. Parker A, Gottesman S. Small RNA regulation of TolC, the outer membrane component of bacterial multidrug transporters. J Bacteriol. 2016;198:1101-1113.

46. Eyraud A, Tattevin P, Chabelskaya S, et al. A small RNA controls a protein regulator involved in antibiotic resistance in Staphylococcus aureus. Nucleic Acids Res. 2014;42:4892-4905.

47. Jeeves RE, Marriott AA, Pullan ST, et al. Mycobacterium tuberculosis is resistant to isoniazid at a slow growth rate by single nucleotide polymorphisms in katG codon Ser315. PLoS One. 2015;10:e138253.

48. Jackson LA, Pan JC, Day MW, et al. Control of RNA stability by NrrF, an iron-regulated small RNA in Neisseria gonorrhoeae. $J$ Bacteriol. 2013;195:5166-5173.

49. Kim JN, Kwon YM. Genetic and phenotypic characterization of the RyhB regulon in Salmonella typhimurium. Microbiol Res. 2013;168:41-49.

50. Gottesman S. Micros for microbes: non-coding regulatory RNAs in bacteria. Trends Genet. 2005;21:399-404.

51. Storz G, Vogel J, Wassarman KM. Regulation by small RNAs in bacteria: expanding frontiers. Mol Cell. 2011;43(6):880-891.

52. Lombardo MJ, Aponyi I, Rosenberg SM. General stress response regulator RpoS in adaptive mutation and amplification in Escherichia coli. Genetics 2004;166:669-680.

53. Gutierrez A, Laureti L, Crussard S, et al. Beta-lactam antibiotics promote bacterial mutagenesis via an RpoS-mediated reduction in replication fidelity. Nat Commun. 2013;4:1610.

54. Kohanski MA, Dwyer DJ, Hayete B, et al. A common mechanism of cellular death induced by bactericidal antibiotics. Cell. 2007;130:797-810.

55. Masse E, Gottesman S. A small RNA regulates the expression of genes involved in iron metabolism in Escherichia coli. Proc Natl Acad Sci U SA. 2002;99:4620-4625. 
56. Thomas VC, Kinkead LC, Janssen A, et al. A dysfunctional tricarboxylic acid cycle enhances fitness of Staphylococcus epidermidis during beta-lactam stress. mBio. 2013;4(4):pii: e00437-13.

57. Fux CA, Shirtliff M, Stoodley P. Can laboratory reference strains mirror "real-world" pathogenesis? Trends Microbiol. 2005;13:58-63.

58. Nikaido H. Structure and mechanism of RND-type multidrug efflux pumps. Adv Enzymol Relat Areas Mol Biol. 2011;77:1-60.

59. Augustus AM, Celaya T, Husain F, et al. Antibiotic-sensitive TolC mutants and their suppressors. J Bacteriol. 2004;186:1851-1860.

60. Mousa JJ, Bruner SD. Structural and mechanistic diversity of multidrug transporters. Nat Prod Rep. 2016;33:1255-1267.

61. Riccardi G, Pasca MR, Buroni S. Mycobacterium tuberculosis: drug resistance and future perspectives. Future Microbiol. 2009;4:597-614.

62. Meier S, Goerke C, Wolz C, et al. SigmaB and the sigmaB-dependent arlRS and yabJ-spoVG loci affect capsule formation in Staphylococcus aureus. Infect Immun. 2007;75:4562-4571.
63. Fernandez L, Hancock RE. Adaptive and mutational resistance: role of porins and efflux pumps in drug resistance. Clin Microbiol Rev. 2012;25:661-681.

64. Mizuno T, Chou MY, Inouye M. A unique mechanism regulating gene expression: translational inhibition by a complementary RNA transcript (micRNA). Proc Natl Acad Sci U S A. 1984;81:1966-1970.

65. DebRoy S, Gebbie M, Ramesh A, et al. A riboswitch-containing sRNA controls gene expression by sequestration of a response regulator. Science. 2014;345:937-940.

66. Ternan NG. Small regulatory RNA molecules in bacteria. OA Microbiol. 2013;1:1.

67. He W, Zhang X, Zhang J, et al. Riboswitch control of induction of aminoglycoside resistance acetyl and adenyl-transferases. RNA Biol. 2013;10:1266-1273.

68. Wendlandt S, Li J, Ho J, et al. Enterococccal multi-resistance gene cluster in methicillin-resistant Staphyloccus aureus from various origins and geographical locaitons. J Antimicrob Chemother. 2014;3:3.
Infection and Drug Resistance

\section{Publish your work in this journal}

Infection and Drug Resistance is an international, peer-reviewed openaccess journal that focuses on the optimal treatment of infection (bacterial, fungal and viral) and the development and institution of preventive strategies to minimize the development and spread of resistance. The journal is specifically concerned with the epidemiology of antibiotic
Dovepress

resistance and the mechanisms of resistance development and diffusion in both hospitals and the community. The manuscript management system is completely online and includes a very quick and fair peerreview system, which is all easy to use. Visit http://www.dovepress.com/ testimonials.php to read real quotes from published authors.

Submit your manuscript here: https://www.dovepress.com/infection-and-drug-resistance-journal 